\title{
S-100 PROTEIN RELEASE IN A RANGE OF CARDIOTHORACIC SURGICAL PROCEDURES
}

\author{
P. Kumar, MA, BM, BCh ${ }^{a}$ K. Dhital, BSc, FRCS, ${ }^{a}$ M. Hossein-Nia, BSc, PhD, ${ }^{\text {b }}$ S. Patel, ${ }^{\text {b }}$ D. Holt, PhD, FRCPath, ${ }^{b}$ \\ and T. Treasure, MD, MS, FRCS, ${ }^{a}$ London, United Kingdom
}

In studies of perioperative brain injury physicians rely on clinically evident stroke to diagnose discrete damage and neuropsychologic tests for global changes. ${ }^{1,2}$ Neurologic examination may miss diffuse injury and infarction in silent areas, and neuropsychologic testing is time-consuming and applicable only if a battery of tests can be performed before the operation and repeated several weeks later under identical circumstances. ${ }^{3}$ S-100 protein promises to be a very practical way of quantifying central nervous system

From the Department of Cardiothoracic Surgery ${ }^{\mathrm{a}}$ and the Analytical Unit,, St. George's Hospital, London, United Kingdom.

Received for publication Oct. 14, 1996; accepted for publication Oct. $29,1996$.

Address for reprints: Tom Treasure, MD, MS, FRCS, Knightsbridge Wing, St. George's Hospital, Blackshaw Rd., London, SW17 0QT, United Kingdom.

J Thorac Cardiovasc Surg 1997;113:953-4.

Copyright (C) 1997 by Mosby-Year Book, Inc.

$0022-5223 / 97 \$ 5.00+0 \quad \mathbf{1 2 / 5 4 / 7 8 9 2 6}$ damage and might overcome both of these deficiencies. $^{4,5}$

S-100 protein is a calcium-binding dimer with alpha and beta subunits. The alpha-beta and beta-beta forms of S-100 are found predominantly in neural tissue, have a half-life of about 2 hours, and are excreted by the kidney. ${ }^{4,5}$ Increased levels of S-100 in the cerebrospinal fluid and serum have been reported after head injury and stroke. We report the results of a preliminary study of a series of patients grouped according the expected magnitude of cerebral hazard.

Methods. Patients were placed into four groups stratified according to increasing risk for cerebral injury. Group 1 comprised patients having a major operation, lung resection, without cardiopulmonary bypass (CPB). All the other patients had CPB with a membrane oxygenator and arterial line filter. Group II had a coronary artery operation at $32^{\circ} \mathrm{C}$ with intermittent ventricular fibrillation and ischemia, group III had aortic root replacement with cold blood cardioplegia and a CPB temperature of $28^{\circ} \mathrm{C}$, and group IV had aortic surgery with a similar CPB technique with, in addition, a period of deep hypothermic circulatory arrest at $18^{\circ} \mathrm{C}$.

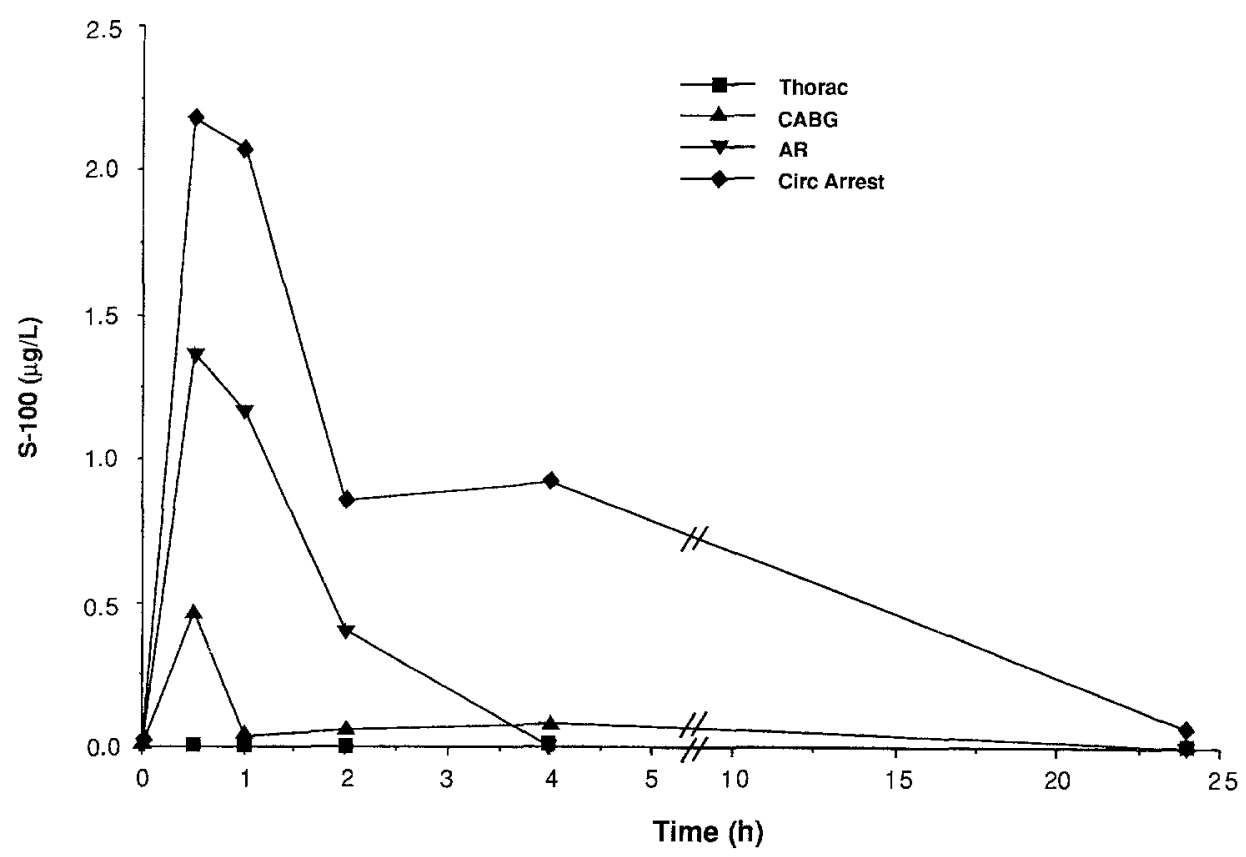

Fig. 1. Median S-100 levels for the four groups against time. $0=$ preoperative level; thereafter, times denote postoperative time. Thorac, Thoracotomy and lung resection; $C A B G$, coronary artery bypass grafting; $A R$, aortic root replacement without circulatory arrest; Circ Arrest, aortic surgery with a period of hypothermic circulatory arrest. 


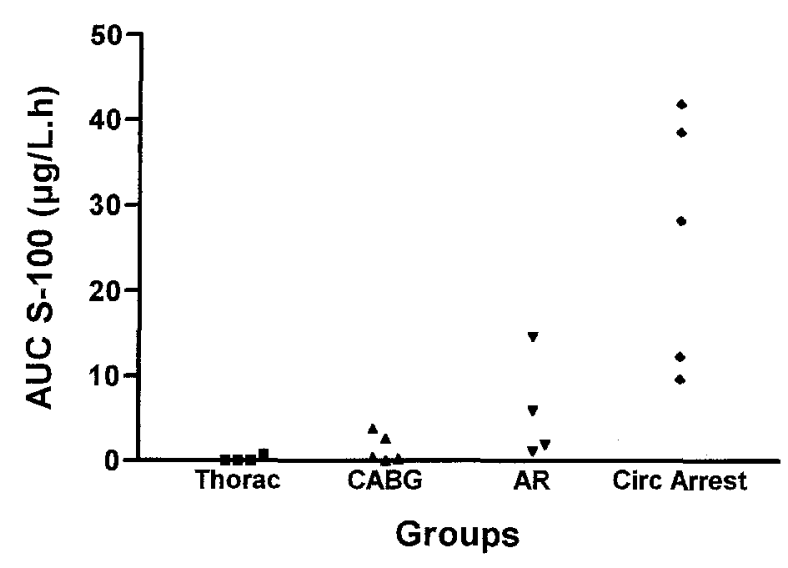

Fig. 2. AUC S-100 for four groups. Thorac, Thoracotomy and lung resection; $C A B G$, coronary artery bypass grafting; $A R$, aortic root replacement without circulatory arrest; Circ Arrest, aortic surgery with a period of hypothermic circulatory arrest.

In all patients we measured the serum $\mathrm{S}-100$ level before the induction of anesthesia. In group I we took further samples at $1 / 2$ hour, 1 hour, 2 hours, 4 hours, and 24 hours after extubation, and we took samples at the same time intervals after the end of CPB for the three cardiac surgical groups. We used immunoradiometric assay to measure the serum S-100 level (Sangtec 100, AB Sangtec Medical, Bromma, Sweden). The Sangtec 100 assay measures the neurospecific isoforms of S-100 protein, and its level is less than $0.2 \mu \mathrm{g} / \mathrm{L}$ in $95 \%$ of the normal healthy population.

Results. Nineteen patients were studied: four underwent lung resection, six had coronary operations, four had aortic root replacement without arrest, and five patients had circulatory arrest for aortic surgery. The mean ages were $66,58,56$, and 64 years. The nadir temperatures were $37^{\circ} \mathrm{C}, 32^{\circ} \mathrm{C}, 28^{\circ} \mathrm{C}$, and $18^{\circ} \mathrm{C}$, respectively, and the CPB times averaged 100,111 , and 109 minutes for the three cardiac groups. All the patients survived the procedure, but there were three deaths in group IV. These three patients had undergone emergency operations for aortic dissection and died 1 , 3 , and 10 days after the operation.

The time course of $\mathrm{S}-100$ protein release for the four groups is shown in Fig. 1. The area under the curve for S-100 (AUC S-100) protein release in every patient is shown in Fig. 2. In group IV, the circulatory arrest times ranged from 9 to 32 minutes and the S-100 AUC from 9.66 to $41.75 \mu \mathrm{g} /$ L.h. The Spearman rank correlation was $0.9(p=0.04)$. There were no clinically evident neurologic events among the survivors.

Discussion. At baseline and in all patients not supported by CPB, the S-100 level was below the limits of detection. The peak and AUC S-100 levels for groups II, III, and IV were proportional to the anticipated hazard and followed a similar pattern. The highest level was usually at 30 minutes and the level was falling by an hour in 15 of 19 patients. By 24 hours after the operation the serum S-100 level had returned to normal. It is important to note that patients in different groups were operated on at different temperatures with the nadirs being $37^{\circ} \mathrm{C}, 32^{\circ} \mathrm{C}, 28^{\circ} \mathrm{C}$, and $18^{\circ} \mathrm{C}$, chosen in line with the intention of protecting the brain from injury. So far as we know, S-100 protein release is not a temperature-related phenomenon, and in our data there was no correlation. However, a larger cohort would be required to confirm this observation.

These results are from a preliminary study. We can make only cautious interpretations of the data, but they support the feasibility of using S-100 to measure brain injury related to surgery. We are in the process of correlating S-100 protein release with changes in neuropsychologic tests to establish its clinical relevance.

\section{REFERENCES}

1. Treasure T. Cerebral protection in adults. In: Yacoub $M$, Pepper JR, editors. Annual of cardiac surgery, 7th ed. London: Current Science, 1994;161-9.

2. Murkin JM, Stanton PN, Stump DA, Blumenthal JA. Statement of consensus on assessment of neurobehavioral outcomes after cardiac surgery. Ann Thorac Surg 1995;59:128995.

3. Newman PN. Analysis and interpretation of neuropsychologic tests in cardiac surgery. Ann Thorac Surg 1995;59:1351-5.

4. Zimmer DB, Cornwall EH, Landar A, et al. The S-100 protein family: history, function and expression. Brain Res Bull 1995; 37:417-29.

5. Johnson LP, Lundquist C, Lindgren A, et al. Cerebral complication after cardiac surgery assessed by S-100 and NSE levels in blood. J Cardiothorac Vasc Anaesth 1995;6:694-9. 